\title{
GENETIC ASSOCIATION AMONG MORPHOLOGICAL TRAITS OF ZEA MAYS SEEDLINGS UNDER SALT STRESS
}

\author{
NAWAZ A, HASEEB A, MALIK HA, *ALI Q, MALIK A \\ Institute of Molecular Biology and Biotechnology, The University of Lahore, Lahore, Pakistan \\ Corresponding author: saim1692@gmail.com
}

(Received, $7^{\text {th }}$ May 2020, Revised $19^{\text {th }}$ August 2020, Published $25^{\text {th }}$ August 2020)

\begin{abstract}
Zea mays is an important cereal crop which has been used by human from last thousands of years as grain crop. It is very sensitive for drought, heat, cold, salinity and heavy metals toxicity. For evaluating corn for salt stress we have conducted an experiment in the greenhouse of IMBB, University of the Lahore. Four maize genotypes were selected for our research work, viz., B-316, EV-1097Q, Raka-poshi and Sahiwal-2002 under the treatments of salt were kept as following: control, 0.2Molar $\mathrm{NaCl}$, 0.5Molar $\mathrm{NaCl}$, 0.7Molar $\mathrm{NaCl}$ and $1 \mathrm{Molar} \mathrm{NaCl}$. The selection of genotypes for high shoot and root length under treatments $0.5 \mathrm{Molar} \mathrm{NaCl}$, 0.7Molar $\mathrm{NaCl}$ may be fruitful for the improvement of crop production and productivity. It was found from results that the B-316 performed better under all stress treatments for seedling traits as compared with EV-1097Q and Sahiwal-2020 maize genotypes. The results showed that higher genetic advance and heritability was recorded for both root length and shoot length. The significant and positive correlation was recorded among root length, shoot length, root dry weight and shoot dry weight. The regression analysis showed that the higher contribution for shoot length was found for root length. It was concluded from our study that the selection of maize genotypes may be fruitful on the basis of root length and shoot length to improve grain yield under salt stress conditions.
\end{abstract}

Keywords: Zea mays, salt stress, genetic advance, regression analysis, root length

\section{Introduction}

The maize (Zea mays L.) as one of an important leading cash and food crops in the world occupied a significant role and position among all of the cultivated crop cultivars of cereal plants (Boomsma et al., 2009). The cultivation or growing of maize is a symbolic of the green revolution which has played an important and pivotal role for fulfillment of nation food and nutrient requirements. It is one of the most important among all of the worldwide fodder as well as food crop plants; in terms for its cultivated crop area which is $0.973 \mathrm{~m}$ ha along with production of grain is $3.707 \mathrm{~m}$ tones however it has productivity potential up to $3805 \mathrm{~kg} \mathrm{ha}^{-1}$ (Anonymous, 2018). It has ability to be grown as below as sea level up to $5000 \mathrm{~m}$ of altitude along with the areas where the rainfall is in the $300-1130 \mathrm{~mm}$ range. The grain availability for maize is increasing due to increasing population affects since (Ali et al., 2012; Buckler et al., 2009). The growing area of maize has been decreasing through every year while very low expectation of increasing area and production in coming future. Therefore, there is an urgent requirement or need for vertical or continuous increase for fodder and grain yield/hectare for insuring the household and livestock food and fee security throughout the world (Edreira and Otegui, 2012; Mustafa et al., 2013; Mustafa et al., 2018). It has been noted that the current climatic effects caused a change in the relation for wheat has become inconclusive along with the model dependent in maize growth, development, grain productivity and yield (Farooq et al., 2015; Saif-ul-malook et al., 2014). It has been found form various research works on climatic changing effects that the increase in temperature and rainfall are interlinked with each other, the increase in the temperature is also causing drought along with salt stress in the temperate, tropical and subtropical regions of the world, there is an average increase in temperature up to $3-4^{\circ} \mathrm{C}$ till end of $21^{\text {th }}$ century throughout the world and South East Asia continent (Gavaghan et al., 2011; Khalil et al., 2020; Mazhar et al., 2020; Zubair et al., 2016). The present study was carried out to evaluate the effects of salt stress on maize seedling morphological traits and association among them.

\section{Materials and methods}

For evaluating maize for salt or $\mathrm{NaCl}$ stress, we have conducted an experiment in the greenhouse of Institute of Molecular Biology and Biotechnology, The University of Lahore, Lahore. Four maize genotypes were selected for our research work, viz.,

[Citation: Nawaz, A., Haseeb, A., Malik, H.A., Ali, Q., Malik, A. (2020). Genetic association among morphological traits of Zea mays seedlings under salt stress. Biol. Clin. Sci. Res. J., 2020: 21 doi: https://doi.org/10.54112/bcsrj.v2020i1.21]. 
B-316, EV-1097Q, Raka-poshi and Shawil-2002. The seeds of selected wheat genotypes were sown in 56 pots. Each of the pot was in triplicate for each of the maize genotype. The treatments of salt were kept as following: T0 (control no any type of treatment), T1 (0.20Molar $\mathrm{NaCl}), \quad \mathrm{T} 2 \quad(0.5$ Molar $\mathrm{NaCl}), \quad \mathrm{T} 3$ $(0.7 \mathrm{Molar} \mathrm{NaCl})$ and $\mathrm{T} 4(1 \mathrm{Molar} \mathrm{NaCl})$. The seeds were sown and after germination, the seedlings were given stress treatments after one week of germination. The salt treatment was carried out through the application of $200 \mathrm{ml}$ water to normal or control plants while $100 \mathrm{ml}$ to the plants under salt stress. The seedling data was recorded for diverse morphological traits, viz., leaf area, roots per plant, dry root weight, root length, shoot length, shoot dry weight. The recorded data was analyzed statistically through the analysis of variance (ANOVA) techniques through using the SPSS23.1 software.

\section{Results and discussions}

It was found from results that the all of the maize genotypes showed $100 \%$ survival under control conditions while it was found that by increasing salt concentrations the performance of maize genotypes for survival under salt stress was decreased. The genotype B-316 showed better survival under all stress conditions. It was also found from results that $\mathrm{du}$ tot increasing salt stress the survival of maize genotypes was decreased. The results from table 2 showed that there were significant differences among the treatments, genotypes and the interactions of treatments and genotypes. It was found that the lower coefficient of variance was recorded for all of the studied traits which revealed that there was consistency among the results of all studied traits (Ashraf et al., 2020; Khalil et al., 2020; Mazhar et al., 2020). The lower coefficient of variance also indicated that the results were reliable for the selection of resistance genotypes of maize against salt effects. The average leaf area under all of the studied traits was recorded as $5.821 \pm 0.0112 \mathrm{~cm}^{2}$, while average roots per plant $(7.017 \pm 0.0106)$, dry root weight $(0.372 \pm 0.0011 \mathrm{~g})$, dry shoot weight $(0.3423 \pm 0.0012 \mathrm{~g})$, root length $(19.231 \pm 1.2352 \mathrm{~cm})$ and shoot length $(8.123 \pm 0.0235 \mathrm{~cm})$ were recorded. It was indicated from results that the higher root length and shoot length under effects of salt revealed the plant tolerance and the chance of selecting maize genotypes against salt stress. The higher genetic advance was recorded for dry shoot weight $(12.383 \%)$, root length $(19.231 \%)$ and shoot length (27.469\%) while higher heritability was recorded for all of the studied traits especially dry shoot weight (91.242\%), root length (94.235\%) and shoot length $(96.245 \%)$. The higher genetic advance and heritability revealed that the selection may be fruitful to improve grain yield and production of maize under salt stress conditions.

Table 1. Survival percentage of maize genotypes under different salt stress conditions

\begin{tabular}{lllll}
\hline Treatments & B-316 & Raka-poshi & EV-1097Q & Sahiwal-2002 \\
\hline Control (T0) & 100 & 100 & 100 & 100 \\
0.2Molar NaCl (T1) & 93.24 & 88.34 & 93.25 & 92.23 \\
0.5Molar NaCl(T2) & 90.57 & 82.24 & 87.26 & 89.34 \\
0.7Molar NaCl (T3) & 89.47 & 79.56 & 83.75 & 81.46 \\
1Molar NaCl (T5) & 86.34 & 77.43 & 80.24 & 78.65 \\
\hline
\end{tabular}

Table 2. Genetic components for morphological traits of maize seedlings

\begin{tabular}{llllcll}
\hline Source & LA & RPP & DRW & DSW & RL & SL \\
\hline Replication & 0.0004 & 0.0267 & 0.0192 & 0.0014 & 0.0041 & 0.0028 \\
Genotypes & $6.0246^{*}$ & $8.1911^{*}$ & $17.671^{*}$ & $2.0171^{*}$ & $9.9432^{*}$ & $8.2231^{*}$ \\
Treatments & $0.3215^{*}$ & $7.2451^{*}$ & $6.924^{*}$ & $11.013^{*}$ & $7.7023^{*}$ & $14.2280^{*}$ \\
Genotypes $\times$ treatments & $0.1420^{*}$ & $3.123^{*}$ & $9.0241^{*}$ & $6.0151^{*}$ & $11.1026^{*}$ & $9.4014^{*}$ \\
Error & 0.0022 & 0.0011 & 0.0711 & 0.0018 & 0.0011 & 0.0031 \\
Grand Mean & 5.821 & 7.017 & 0.372 & 0.34231 & 19.231 & 9.261 \\
Coefficient of variance (\%) & 2.37 & 3.232 & 3.56 & 5.432 & 6.213 & 8.123 \\
Standard Error & 0.0112 & 0.0106 & 0.0011 & 0.0012 & 1.3241 & 0.0235 \\
Genetic advance & 8.541 & 7.252 & 7.391 & 12.383 & 17.2443 & 27.469 \\
Broad sense heritability & 89.234 & 87.535 & 90.128 & 91.242 & 94.235 & 96.245 \\
\hline
\end{tabular}

$*=$ Significant at $5 \%$ probability level, $\mathrm{DRW}=$ dry root weight, $\mathrm{FRW}=$ fresh root weight, $\mathrm{RL}=$ root length, $\mathrm{SL}=$ shoot length, RPP = roots per plant, $\mathrm{LA}=$ leaf area

The results from table 3 indicated that the higher shoot length of B-316 was found higher under control and 1 Molar $\mathrm{NaCl}$ treatment $(8.560 \mathrm{~cm}, 8.556 \mathrm{~cm})$ respectively, root length $(19.360 \mathrm{~cm})$ under 1 Molar
$\mathrm{NaCl}$, leaf area $\left(5.770 \mathrm{~cm}^{2}\right)$, number of roots $(6.660)$, shoot dry weight $(0.290 \mathrm{~g})$ and root dry weight $(0.281 \mathrm{~g})$ under 0.7 Molar $\mathrm{NaCl}$ concentration. The higher shoot length $(9.710 \mathrm{~cm})$ of Raka-poshi was

[Citation: Nawaz, A., Haseeb, A., Malik, H.A., Ali, Q., Malik, A. (2020). Genetic association among morphological traits of Zea mays seedlings under salt stress. Biol. Clin. Sci. Res. J., 2020: 21 doi: https://doi.org/10.54112/bcsrj.v2020i1.21]. 
found along with higher root length $(22.140 \mathrm{~cm})$ and leaf area $\left(6.950 \mathrm{~cm}^{2}\right)$ under 1 Molar $\mathrm{NaCl}$, while, number of roots (6.660) and shoot dry weight $(0.360 \mathrm{~g})$ under $0.7 \mathrm{Molar} \mathrm{NaCl}$ and root dry weight $(0.350 \mathrm{~g})$ under $0.2 \mathrm{Molar} \mathrm{NaCl}$ concentration. The higher shoot length $(8.66 \mathrm{~cm})$ of EV-1097Q was found along with higher root length $(22.560 \mathrm{~cm})$ and leaf area $\left(7.10 \mathrm{~cm}^{2}\right)$ under $0.5 \mathrm{Molar} \mathrm{NaCl}$, while, number of roots (7.860) and shoot dry weight $(0.330 \mathrm{~g})$ under $0.2 \mathrm{Molar} \mathrm{NaCl}$ and root dry weight $(0.332 \mathrm{~g})$ under 1 Molar $\mathrm{NaCl}$ concentration. The higher shoot length $(9.622 \mathrm{~cm})$ of Sahiwal-2002 was found along with higher root length $(18.464 \mathrm{~cm})$ and leaf area $\left(7.453 \mathrm{~cm}^{2}\right)$ under $0.2 \mathrm{Molar} \mathrm{NaCl}$, while, number of roots (7.564), shoot dry weight $(0.321 \mathrm{~g})$ and root dry weight $(0.327 \mathrm{~g})$ under 1 Molar $\mathrm{NaCl}$ concentration. The higher root length under salt stress conditions indicated that the plants showed tolerance against salt stress and helped to improve shoot length of maize seedlings under salt stress conditions (Mazhar et al., 2020; Mupangwa et al., 2007; Mustafa et al., 2013). The selection of maize genotypes on the basis of higher root length and shoot length may be helpful to improve the salt stress tolerance in maize genotypes and selected genotypes may be used for the development of maize hybrids and synthetic varieties (Ali et al., 2013; Ali et al., 2016; Masood et al., 2015).

Table 3. Mean comparison for maize genotypes under different salt concentrations

\begin{tabular}{|c|c|c|c|c|c|c|c|}
\hline Genotypes & Treatments & SL & RL & LA & NR & SDW & RDW \\
\hline \multicolumn{8}{|l|}{ B-316 } \\
\hline & Control (T0) & $8.560 \mathrm{a}$ & $18.660 \mathrm{~b}$ & $4.670 \mathrm{~b}$ & $6.660 \mathrm{a}$ & $0.280 \mathrm{~b}$ & $0.275 b$ \\
\hline & 0.2Molar $\mathrm{NaCl}(\mathrm{T} 1)$ & $7.550 \mathrm{~b}$ & $18.200 \mathrm{c}$ & $4.680 \mathrm{~b}$ & $6.460 \mathrm{~b}$ & $0.275 \mathrm{c}$ & $0.276 b$ \\
\hline & 0.5Molar $\mathrm{NaCl}(\mathrm{T} 2)$ & $8.558 \mathrm{a}$ & $18.660 \mathrm{~b}$ & $4.660 \mathrm{~b}$ & $6.660 \mathrm{a}$ & $0.278 \mathrm{c}$ & $0.280 \mathrm{a}$ \\
\hline & 0.7Molar $\mathrm{NaCl}$ (T3) & $8.560 \mathrm{a}$ & $19.260 \mathrm{a}$ & $5.770 \mathrm{a}$ & $6.660 \mathrm{a}$ & $0.290 \mathrm{a}$ & $0.281 \mathrm{a}$ \\
\hline & 1Molar $\mathrm{NaCl}$ (T5) & $8.559 a$ & $19.360 \mathrm{a}$ & $5.750 \mathrm{a}$ & $6.560 \mathrm{~b}$ & $0.290 \mathrm{a}$ & $0.269 \mathrm{c}$ \\
\hline \multicolumn{8}{|l|}{ Raka-poshi } \\
\hline & Control (T0) & $7.679 c$ & $19.540 \mathrm{~b}$ & $5.920 b$ & $6.610 \mathrm{~b}$ & $0.350 \mathrm{~b}$ & $0.329 \mathrm{c}$ \\
\hline & 0.2Molar $\mathrm{NaCl}(\mathrm{T} 1)$ & $9.710 \mathrm{a}$ & $17.040 \mathrm{c}$ & $5.850 \mathrm{~b}$ & $7.710 \mathrm{a}$ & $0.360 \mathrm{a}$ & $0.350 \mathrm{a}$ \\
\hline & 0.5Molar $\mathrm{NaCl}(\mathrm{T} 2)$ & $8.706 \mathrm{~b}$ & $17.140 \mathrm{c}$ & $5.840 \mathrm{~b}$ & $7.710 \mathrm{a}$ & $0.358 \mathrm{~b}$ & $0.348 b$ \\
\hline & 0.7Molar $\mathrm{NaCl}$ (T3) & $8.709 b$ & $17.140 \mathrm{c}$ & $5.860 \mathrm{~b}$ & $7.610 \mathrm{a}$ & $0.360 \mathrm{a}$ & $0.349 b$ \\
\hline & 1Molar $\mathrm{NaCl}$ (T5) & $7.679 c$ & $22.140 \mathrm{a}$ & $6.950 \mathrm{a}$ & $6.610 \mathrm{~b}$ & $0.338 \mathrm{c}$ & $0.341 b$ \\
\hline \multicolumn{8}{|l|}{ EV-1097Q } \\
\hline & Control (T0) & $9.667 \mathrm{a}$ & $17.360 \mathrm{c}$ & $6.040 \mathrm{c}$ & $7.960 \mathrm{a}$ & $0.328 \mathrm{~b}$ & $0.339 \mathrm{a}$ \\
\hline & 0.2Molar $\mathrm{NaCl}(\mathrm{T} 1)$ & $8.66 b$ & $17.36 \mathrm{c}$ & $6.06 \mathrm{c}$ & $7.86 \mathrm{a}$ & $0.33 \mathrm{a}$ & $0.33 c$ \\
\hline & 0.5Molar $\mathrm{NaCl}(\mathrm{T} 2)$ & $7.64 \mathrm{c}$ & $22.56 \mathrm{a}$ & $7.15 \mathrm{a}$ & $6.96 \mathrm{~b}$ & $0.309 \mathrm{c}$ & $0.331 \mathrm{c}$ \\
\hline & 0.7Molar $\mathrm{NaCl}$ (T3) & $7.641 \mathrm{c}$ & $22.36 \mathrm{a}$ & $7.15 \mathrm{a}$ & $6.86 \mathrm{~b}$ & $0.308 \mathrm{c}$ & $0.333 \mathrm{c}$ \\
\hline & 1Molar $\mathrm{NaCl}$ (T5) & $8.662 b$ & $18.16 b$ & $6.26 b$ & $6.86 \mathrm{~b}$ & $0.33 \mathrm{a}$ & $0.332 b$ \\
\hline \multicolumn{8}{|c|}{ Sahiwal-2002 } \\
\hline & Control (T0) & $7.522 \mathrm{~d}$ & $17.24 \mathrm{c}$ & $6.346 b$ & $7.454 a$ & $0.332 \mathrm{a}$ & $0.322 \mathrm{c}$ \\
\hline & 0.2Molar $\mathrm{NaCl}(\mathrm{T} 1)$ & $9.622 \mathrm{a}$ & $18.464 \mathrm{a}$ & $7.453 \mathrm{a}$ & $7.324 b$ & $0.321 b$ & $0.314 d$ \\
\hline & 0.5Molar $\mathrm{NaCl}(\mathrm{T} 2)$ & $9.612 b$ & $16.758 \mathrm{~d}$ & $6.354 b$ & $6.243 c$ & $0.311 b$ & $0.325 b$ \\
\hline & 0.7Molar $\mathrm{NaCl}$ (T3) & $7.521 \mathrm{~d}$ & $18.256 \mathrm{~b}$ & $6.453 b$ & $7.564 a$ & $0.321 b$ & $0.327 \mathrm{a}$ \\
\hline & 1Molar $\mathrm{NaCl}$ (T5) & $8.532 \mathrm{c}$ & $16.885 \mathrm{~d}$ & $7.543 \mathrm{a}$ & $7.345 b$ & $0.301 \mathrm{c}$ & $0.311 \mathrm{e}$ \\
\hline
\end{tabular}

DRW = dry root weight, DSW = dry shoot weight, $\mathrm{RL}=$ root length, $\mathrm{SL}=$ shoot length, $\mathrm{RPP}=$ roots per plant, $\mathrm{LA}=$ leaf area

The results from table 4 revealed that there was a significant correlation between number of roots and leaf area, dry root weight, and root length. The positive and significant correlation was found between leaf area and dry root weight, root length and number of roots per plant. The root length was significantly and positively correlated with leaf area, shoots length, number of roots per plant, dry root weight, dry shoot weight while negatively and significantly correlated with dry shoot weight. The shoot length was positively and significantly correlated with dry shoot weight and root length. The significant and positive correlation of root length, shoot length, dry root weight indicated that the selection of maize genotypes for improving grain yield and productivity under salt stress conditions may be helpful (Ali et al., 2014; Ali et al., 2011; Saiful-malook et al., 2014).

Table 4. Correlation among morphological traits of maize

\begin{tabular}{llllll}
\hline Traits & LA & RPP & DRW & DSW & RL \\
\hline RPP & $0.7654^{*}$ & & & &
\end{tabular}

[Citation: Nawaz, A., Haseeb, A., Malik, H.A., Ali, Q., Malik, A. (2020). Genetic association among morphological traits of Zea mays seedlings under salt stress. Biol. Clin. Sci. Res. J., 2020: 21 doi: https://doi.org/10.54112/bcsrj.v2020i1.21]. 


\begin{tabular}{llllll} 
DRW & $0.3776^{*}$ & $0.6769^{*}$ & & & \\
DSW & 0.0344 & -0.0834 & -0.0553 & & \\
RL & $0.5867^{*}$ & $0.7863^{*}$ & $0.8536^{*}$ & $-0.3739^{*}$ & \\
SL & -0.6556 & 0.0463 & -0.2038 & $0.7948^{*}$ & $0.8948^{*}$ \\
\hline
\end{tabular}

* = Significant at $5 \%$ probability level, DRW = dry root weight, $\mathrm{FRW}=$ fresh root weight, $\mathrm{RL}=$ root length, $\mathrm{SL}=$ shoot length, $\mathrm{RPP}=$ roots per plant, $\mathrm{LA}=$ leaf area

The regression analysis was carried out to find out the contribution of different traits to improve shoot length (Table 5), it was found that the higher contribution for improving shoot length was recorded for root length (7.544) followed by dry shoot weight (3.113) and leaf area (1.231) while negative contribution was reported for dry root weight (1.130) and number of root per plant 9-0.003). The positive contribution indicated that the shoot length will also be increased due to increase in the root length, leaf area and dry shoot weight. The coefficient of determination was recorded as $68.23 \%$ while revealed that selection of maize genotypes may be helpful to improve grain yield and production under salt stress conditions however the process of selection may be delayed for more improvements in traits of maize genotypes (Ali et al., 2016; Buckler et al., 2009; Khalil et al., 2020; Tahir et al., 2020). The regression equation predicted may be written as $\mathrm{Y}=$ $1.217+7.544(\mathrm{RL})=1.231(\mathrm{LA})-$ $1.130(\mathrm{DRW})+3.113$ (DSW)-0.003(RPP)

Table 5. Regression analysis for shoot length among morphological traits of maize

\begin{tabular}{lllllll}
\hline Traits & Coefficients & $\begin{array}{l}\text { Standard } \\
\text { Error }\end{array}$ & t Stat & Partial R $^{\mathbf{2}}$ & $\begin{array}{l}\text { Lower } \\
\mathbf{9 5 \%}\end{array}$ & $\begin{array}{l}\text { Upper } \\
\mathbf{9 5 \%}\end{array}$ \\
\hline RL & 7.544 & 0.0023 & -0.0231 & 0.8643 & 0.0023 & 0.036 \\
LA & 1.231 & 0.0112 & 0.2324 & 0.3352 & -0.0351 & 0.3524 \\
DRW & -1.130 & 0.0212 & 1.3643 & 0.1356 & -0.0235 & 0.3235 \\
DSW & 3.113 & 0.0232 & -5.5356 & 0.0133 & 1.3156 & 2.3532 \\
RPP & -0.003 & 0.104 & 0.4903 & 0.6235 & -0.0235 & 0.0546 \\
\hline
\end{tabular}

$\mathrm{Y}=1.217$, Multiple $\mathrm{R}^{2}=0.8534, \mathrm{R}^{2}=0.6823$, Adjusted $\mathrm{R}^{2}=0.6424$, Standard Error $=0.0231 \mathrm{DRW}=$ dry root weight, $\mathrm{FRW}=$ fresh root weight, $\mathrm{RL}=$ root length, $\mathrm{RPP}=$ roots per plant, $\mathrm{LA}=$ leaf area

\section{Conclusions}

It was concluded from our study that the B-316 performed better under all stress treatments for seedling traits as compared with EV-1097Q and Sahiwal-2020 maize genotypes. The correlation and regression analysis showed that the selection of maize genotypes for improving grain yield and production under slat stress conditions on the basis of root length, shoot length and shoot dry weight may be fruitful.

\section{Conflict of interest}

The authors declare absence of any conflict of interest.

\section{References}

Ali, Q., Ahsan, M., Ali, F., Aslam, M., Khan, N. H., Munzoor, M., Mustafa, H. S. B., and Muhammad, S. (2013). Heritability, heterosis and heterobeltiosis studies for morphological traits of maize (Zea mays L.) seedlings. Advancements in Life sciences $\mathbf{1}$.

Ali, Q., Ahsan, M., Kanwal, N., Ali, F., Ali, A., Ahmed, W., Ishfaq, M., and Saleem, M. (2016). Screening for drought tolerance: comparison of maize hybrids under water deficit condition. Advancements in Life Sciences 3, 51-58.
Ali, Q., Ahsan, M., Tahir, M. H. N., and Basra, S. M. A. (2012). Genetic evaluation of maize (Zea mays L.) accessions for growth related seedling traits. International Journal for Agro Veterinary and Medical Sciences 6, 164-172.

Ali, Q., Ali, A., Ahsan, M., Nasir, I. A., Abbas, H. G., and Ashraf, M. A. (2014). Linex Tester analysis for morpho-physiological traits of Zea mays L seedlings. Advancements in Life sciences 1, 242-253.

Ali, Q., Hammad, M., Tahir, N., Ahsan, M., Basra, S. M. A., Farooq, J., and Elahi, M. (2011). Correlation and path coefficient studies in maize (Zea mays L.) genotypes under $40 \%$ soil moisture contents. African Journal of Bacteriology Research 3, 77-82.

Anonymous (2018). "Economic Survey of Pakistan. Govt. of Pakistan, Finance and Economic Affairs Division, Islamabad.."

Ashraf, A., Rashid, M., Ali, Q., and Malik, A. (2020). Genetic Advances and Heritability Analysis for Seedling Growth Traits in Zea mays under Heavy Metal Stress. Genetics and Molecular Research 19.

Boomsma, C. R., Santini, J. B., Tollenaar, M., and Vyn, T. J. (2009). Maize morphophysiological

[Citation: Nawaz, A., Haseeb, A., Malik, H.A., Ali, Q., Malik, A. (2020). Genetic association among morphological traits of Zea mays seedlings under salt stress. Biol. Clin. Sci. Res. J., 2020: 21 doi: https://doi.org/10.54112/bcsrj.v2020i1.21]. 
responses to intense crowding and low nitrogen availability: An analysis and review. Agronomy Journal 101, 1426-1452.

Buckler, E. S., Holland, J. B., Bradbury, P. J., Acharya, C. B., Brown, P. J., Browne, C., Ersoz, E., Flint-Garcia, S., Garcia, A., and Glaubitz, J. C. (2009). The genetic architecture of maize flowering time. Science 325, 714-718.

Edreira, J. I. R., and Otegui, M. E. (2012). Heat stress in temperate and tropical maize hybrids: Differences in crop growth, biomass partitioning and reserves use. Field Crops Research 130, 8798.

Farooq, M., Hussain, M., Wakeel, A., and Siddique, K. H. (2015). Salt stress in maize: effects, resistance mechanisms, and management. A review. Agronomy for Sustainable Development 35, 461-481.

Gavaghan, C. L., Li, J. V., Hadfield, S. T., Hole, S., Nicholson, J. K., Wilson, I. D., Howe, P. W., Stanley, P. D., and Holmes, E. (2011). Application of NMR-based metabolomics to the investigation of salt stress in maize (Zea mays). Phytochemical Analysis 22, 214-224.

Khalil, M., Rashid, M., Ali, Q., and Malik, A. (2020). Genetic Evaluation for Effects of Salt and Drought Stress on Growth Traits of Zea mays Seedlings. Genetics and Molecular Research 19.

Masood, S. A., Jabeen, S., Anum, M., Naseem, Z., Jamshaid, A., and Ali, Q. (2015). Genetic Association of transcriptional factors (OsAP2 gene family) to incorporate drought tolerance in rice. Life Science Journal 12, 71-76.

Mazhar, T., Ali, Q., and Malik, M. S. R. A. (2020). Effects of salt and drought stress on growth traits of Zea mays seedlings. Life Science Journal 17.

Mupangwa, W., Twomlow, S., Walker, S., and Hove, L. (2007). Effect of minimum tillage and mulching on maize (Zea mays L.) yield and water content of clayey and sandy soils. Physics and chemistry of the earth, parts $A / B / C$ 32, 1127-1134.

Mustafa, H. S. B., Ahsan, M., Aslam, M., Ali, Q., Bibi, T., and Mehmood, T. (2013). Genetic variability and traits association in maize (Zea mays L.) accessions under drought stress. Journal of Agricultural Research (03681157) 51.

Mustafa, H. S. B., Mahmood, T., Hameed, A., and Ali, Q. (2018). Enhancing food security in arid areas of Pakistan through newly developed drought tolerant and short duration mustard (Brassica juncea L.) Canola. Genetika 50, 21-31.

Saif-ul-malook, M. A., Ali, Q., and Mumtaz, A. (2014). Inheritance of yield related traits in maize (Zea mays) under normal and drought conditions. Nat Sci 12, 36-49.

Tahir, M., Rashid, M., Ali, Q., and Malik, A. (2020). Evaluation of Genetic Variability in Wheat and Maize under Heavy Metal and Drought Stress. Genetics and Molecular Research 19.

Zubair, M., Shakir, M., Ali, Q., Rani, N., Fatima, N., Farooq, S., Shafiq, S., Kanwal, N., Ali, F., and Nasir, I. A. (2016). Rhizobacteria and phytoremediation of heavy metals. Environmental Technology Reviews 5, 112-119.

\section{(c) (†) \&}

Open Access This article is licensed under a Creative Commons Attribution 4.0 International License, which permits use, sharing, adaptation, distribution and reproduction in any medium or format, as long as you give appropriate credit to the original author(s) and the source, provide a link to the Creative Commons licence, and indicate if changes were made. The images or other third party material in this article are included in the article's Creative Commons licence, unless indicated otherwise in a credit line to the material. If material is not included in the article's Creative Commons licence and your intended use is not permitted by statutory regulation or exceeds the permitted use, you will need to obtain permission directly from the copyright holder. To view a copy of this licence, visit http://creativecommons.org/licen ses/by/4.0/.

(C) The Author(s) 2021

[Citation: Nawaz, A., Haseeb, A., Malik, H.A., Ali, Q., Malik, A. (2020). Genetic association among morphological traits of Zea mays seedlings under salt stress. Biol. Clin. Sci. Res. J., 2020: 21 doi: https://doi.org/10.54112/bcsrj.v2020i1.21]. 